\title{
The presence of dental fluorosis in the permanent dentition in Doha
}

A. Khalid

$$
\text { وعامرد التَفَلُّ (فُرْط الفلوريد السني) في الأسنان الدائمة في العاصمة القَطرَية: الدوحة }
$$

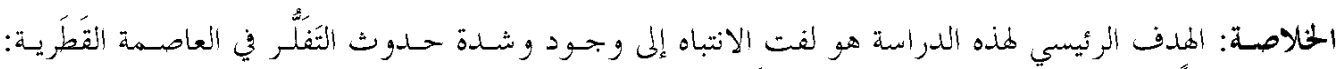

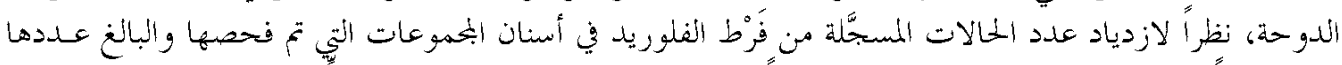

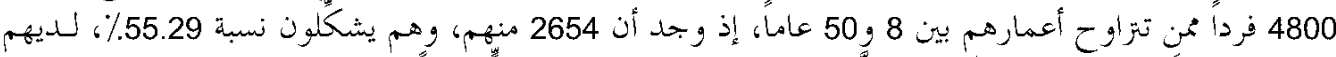

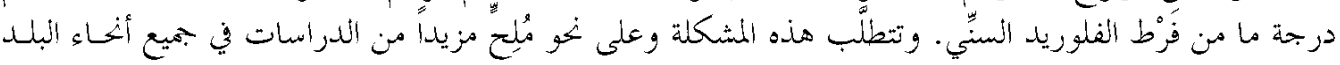

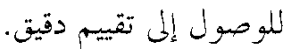

ABSTRACT The main purpose of this study is to draw attention to the presence and the severity of dental fluorosis in Doha (Qatar) through the high level of registered cases of fluorosis found among the groups examined. Of 4800 people aged 8-50 years, 2654 (55.29\%) had dental fluorosis of some degree. This problem urgently requires more studies throughout the country to provide an accurate assessment.

\section{Présence de fluorose dans la dentition permanente à Doha}

RESUME Cette étude avait pour objectif principal d'attirer l'attention sur la présence et la gravité de la fluorose dentaire à Doha (Qatar) du fait du nombre élevé de cas enregistrés de fluorose trouvé dans les groupes examinés. Sur les 4800 personnes âgées de 8 à 50 ans, 2654 (55,29\%) avaient une fluorose dentaire à un certain degré. Ce problème nécessite impérativement des études plus poussées dans l'ensemble du pays pour permettre une évaluation exacte.

${ }^{1}$ Medical Services of Qatar Army Forces, Doha, Qatar.

Received: 07/11/02; accepted 21/06/03

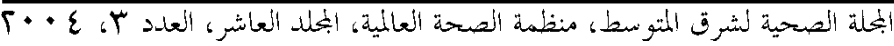




\section{Introduction}

Dental fluorosis is one of main epidemic dental diseases which affect people where the intake of fluoride exceeds normal levels at the time of tooth formation. A fluoride concentration of $0.5-1.2 \mathrm{mg} / \mathrm{L}$ is an accepted level in water [1]. The severity increases with increase in fluoride intake [2-10]. This disease occurs due to toxic effects on the ameloblast cells during the formative stage of tooth development, leading to defective enamel formation [8-10]. The disease starts as chalky-white spots, which later turn to brown [8]. Contralateral teeth, and to a certain extent upper and lower teeth, show similar severity of fluorosis [11,12].

Fluoride is obtained from air originating in fluoride-containing soils, gases, industrial water and burning domestic coal and from foodstuffs such as fish, cereals, banana, potato and tea. Well-water may contain up to $10 \mathrm{ppm}$ fluoride or even more [12]. Individual susceptibility to fluorosis is variable [13-17].

Several types of dental treatment for fluorosis have been reported [16]. Additionally, high fluoride content could be reduced using granulated bone charcoal household de-fluoridation of water for drinking and cooking [13].

This study was carried out to investigate the prevalence of dental fluorosis in Doha as an initial parameter for Qatar State, where no studies on this problem have been done.

\section{Methods}

A simple survey was made after examination for dental fluorosis of people of both sexes between the ages of 8 and 50 years in Doha who attended Gharafa Medical Complex from April 2000 to February 2003.
The permanent teeth were the only ones examined. The examinations were carried out by 1 dentist to standardize the readings. The total number of people examined was 4800. Each person's teeth were carefully examined in natural light after they were dried $[2,12,18]$. The Jackson index of dental fluorosis was used for classification owing to its simplicity to apply and evaluate (Table 1) $[2,18,19]$. The results were classified according to age and severity.

\section{Results}

Table 2 and Figure 1 demonstrate the incidence and class of fluorosis in each age group, and clearly show the prevalence of more advanced fluorosis in the older age groups.

The results show that 2654 persons (55.29\%) of the 4800 examined had dental fluorosis at different stages. Class II and Class III fluorosis was more common in the 15-24 and 25-50 age groups, while Class I was more frequent in the 8-14 age group (Figure 1).

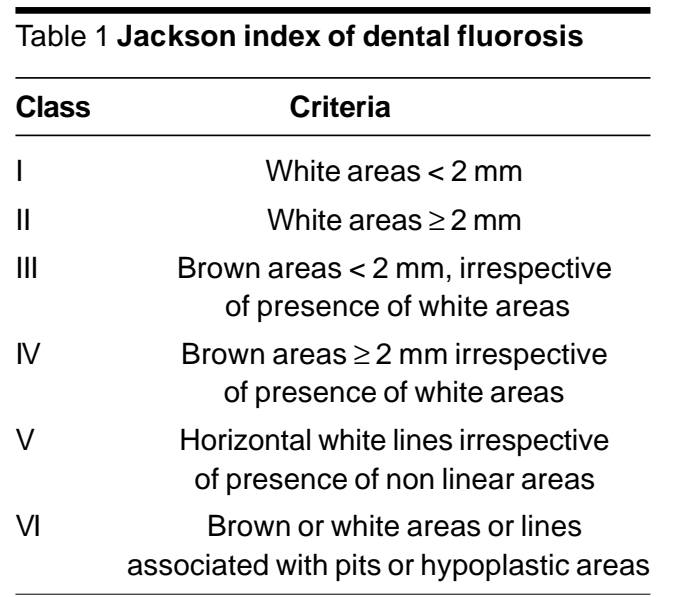

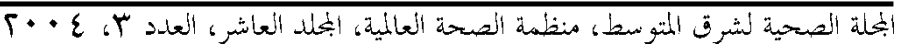


Table 2 Distribution of fluorosis in 4800 patients in Doha according to the Jackson index

\begin{tabular}{|c|c|c|c|c|c|c|c|c|c|c|c|c|c|}
\hline $\begin{array}{l}\text { Age } \\
\text { (years) }\end{array}$ & $\begin{array}{c}\text { No. } \\
\text { patients } \\
\text { examined }\end{array}$ & $\begin{array}{c}\text { No. patients } \\
\text { with } \\
\text { fluorosis }\end{array}$ & s \% & $\begin{array}{c}\text { Class } \\
I\end{array}$ & $\%^{a}$ & $\begin{array}{c}\text { Class } \\
\text { II }\end{array}$ & $\%^{a}$ & $\begin{array}{c}\text { Class } \\
\text { III }\end{array}$ & $\%^{a}$ & $\begin{array}{c}\text { Class } \\
\text { IV }\end{array}$ & $\%^{a}$ & $\begin{array}{c}\text { Class } \\
V\end{array}$ & $\%$ \\
\hline $8-14$ & 800 & 187 & 23.38 & 123 & 65.78 & 64 & 34.22 & - & - & _ & - & - & - \\
\hline $15-24$ & 1500 & 609 & 40.60 & 111 & 18.23 & 207 & 34.00 & 267 & 43.84 & 24 & 3.94 & - & _- \\
\hline $25-50$ & 2500 & 1858 & 74.32 & 336 & 18.08 & 958 & 51.56 & 424 & 22.82 & 85 & 4.57 & 55 & 2.96 \\
\hline Total & 4800 & 2654 & 55.29 & 570 & 21.48 & 1229 & 46.31 & 691 & 26.04 & 109 & 4.11 & 55 & 2.07 \\
\hline
\end{tabular}

a Percentage of the total number with fluorosis.

\section{Discussion}

These results can be explained by the cumulative effects of fluoride in the body and on teeth. The teeth of older patients are exposed to the effects of fluoride for longer than those of younger people. Consequently, they will establish the secondary features of fluorosis $[10,11,14-17]$. Hence, Class V fluorosis was found only in older patients (25-50 years).

The findings of this study are in accordance with those of studies which have been done on the prevalence of dental fluorosis in other parts of the world $[2,3,14,15,17-19]$. No research has yet been done to identify the extent of this problem in the Gulf area, so this study draws attention to the existence of the problem in this area. Moreover, this is the first study which has been done to examine the extent of the condition in Qatar. An evaluation study to compare the distribution pattern and the etiology of fluorosis in Qatar is required.

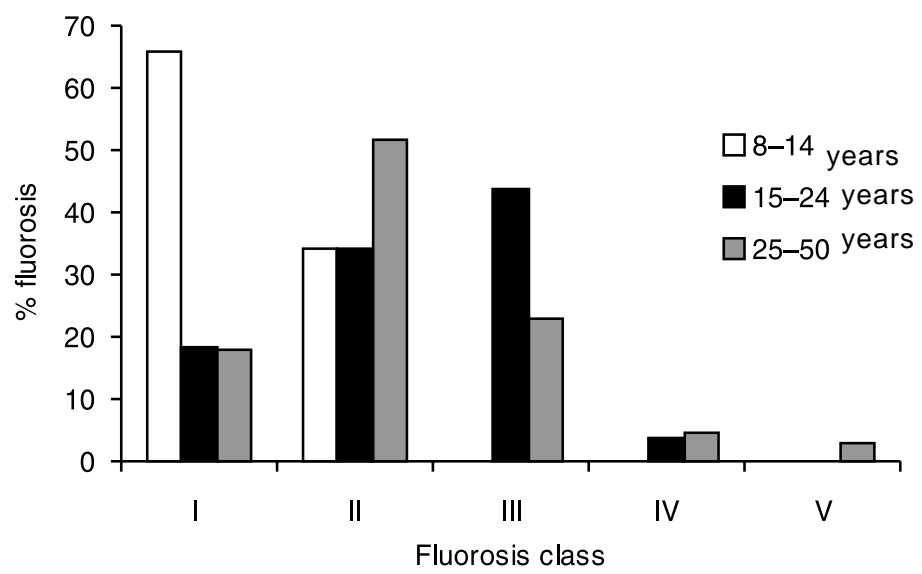

Figure 1 Prevalence of fluorosis in three age groups according to Jackson index

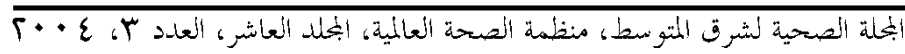




\section{References}

1. Murray JJ. Prevention of oral disease, 3rd ed. Oxford, Oxford University Press, 1995:212-29.

2. Hassan AK, Bosaif M, Najim ZN. Prevalence of dental fluorosis in south Libya. Bahrein medical journal, 2002, 14:85-9.

3. Mitchell L, Mitchell DA. Oxford handbook of clinical dentistry, 1st ed. Oxford, Oxford University Press, 1992:21-7.

4. Black GV, McKay FS. Mottled teeth. Dental cosmos, 1916, 58(2):129.

5. Goldstein RE et al. Bleaching of vital and pulpless teeth. In: Cohens S, Burns RC, eds. Pathways of the pulp, 6th ed. St. Louis, Mosby, 1994:585-603.

6. Fluorides and oral health: Report of a WHO expert committee on oral health status and fluoride use. Geneva, World Health Organization, 1994:12-16 (WHO Technical Report Series No. 846).

7. Smith BGN et al. Pickard's manual of operative dentistry, 4th ed. Oxford, Oxford University Press, 1995:13-8.

8. Cawson et al. Essential oral surgery and pathology. Edinburgh, Churchill Livingstone, 1990:221-7.

9. Schafer WG, Hine MK, Levy BM. Textbook of oral pathology, 3rd ed. Philadelphia, WB Saunders Company, 1974: 301-90.

10. Eversole LR. Clinical outline of oral pathology: diagnosis and treatment. Philadelphia, Lea \& Febiger, 1992:421-4.
11. Thylstrup A, Fejerskov O. Clinical appearance of dental fluorosis in permanent teeth in relation to histologic changes. Community dentistry and oral epidemiology, 1978, 6(6):329-37.

12. Van Palenstein Hederman WH et al. Two types of intraoral distribution of fluorotic enamel. Community dentistry and oral epidemiology, 1997, 25:251-5.

13. Guidelines for drinking water quality, 2nd ed., Vols. 1 and 2. Geneva, World Health Organization, 1993.

14. Pendrys DG, Katz RV, Morse DE. Risk factors for enamel fluorosis in a fluoridated population. American journal of epidemiology, 1994, 140(5):461-71.

15. Recent advances in oral health: report of a WHO expert committee. Geneva, World Health Organization, 1992 (WHO Technical Report Series No. 826).

16. Albers HF. Lightening natural teeth. ADEPT report, 1991, 2(1):10-24.

17. Thylstrup A. Distribution of dental fluorosis in the primary dentition. Community dentistry and oral epidemiology, 1978, 6:329-37.

18. Jackson RD et al. Dental fluorosis and caries prevalence in children residing in communities with different levels of fluoride. Journal of public health dentistry, 1995, 55(2):79-84.

19. Oral health surveys basic methods, 4th ed. Geneva, World Health Organization, 1997:35-8. 